\title{
PENGARUH MEDIA FILTRASI ARANG AKTIF TERHADAP KEKERUHAN, WARNA DAN TDS PADA AIR TELAGA DI DESA BALONGPANGGANG
}

\author{
Sulastri $^{\star \star}$ ) dan Indah Nurhayati ${ }^{\star}$ )
}

\begin{abstract}
Abstrak :
Tujuan dari penelitian ini adalah untuk menurunkan kadar kekeruhan, warna dan total dissolved solid (TDS), pada air telaga di desa Balong Panggang. Reaktor filtrasi yang digunakan dalam penelitian ini adalah : Reaktor Filtrasi 1 dengan komposisi media spon $5 \mathrm{~cm}$, ijuk $10 \mathrm{~cm}$, koral $20 \mathrm{~cm}$, pasir $20 \mathrm{~cm}$ dan arang aktif $10 \mathrm{~cm}$. Reaktor Filtrasi 2 dengan komposisi media spon $5 \mathrm{~cm}$, ijuk $10 \mathrm{~cm}$, koral $20 \mathrm{~cm}$, pasir $20 \mathrm{~cm}$ dan arang aktif $20 \mathrm{~cm}$ dengan debit 2 liter per menit. Dari hasil penelitian ini dapat disimpulkan bahwa filtrasi 2 dengan komposisi media spon $5 \mathrm{~cm}$, ijuk $10 \mathrm{~cm}$, koral $20 \mathrm{~cm}$, pasir $20 \mathrm{~cm}$ dan arang aktif $20 \mathrm{~cm}$ lebih efektif dalam menurunkan kadar kekeruhan (89,41\%), warna $(90,91 \%)$ dan total dissolved solid $(77,88 \%)$, karena semakin banyak media arang aktif maka semakin banyak kadar kekeruhan, warna dan TDS yang diabsorbsi oleh arang aktif.
\end{abstract}

Kata Kunci : Air Telaga, TDS, Kekeruhan, dan Warna

\section{PENDAHULUAN}

Untuk mencukupi kebutuhan seharihari masyarakat di desa balongpanggang menggunakan air telaga. Banyaknya keluhan masyarakat mengenai air telaga yang keruh dan berwarna di musim hujan maupun kemarau. Dengan demikian maka peneliti mencoba menggunakan teknologi tepat guna dalam menurunkan kekeruhan dan warna dengan menggunakan media pengolah pasir,, ijuk, koral dan karbon aktif agar air yang digunakan layak sebagai air bersih. Persyaratan kualitas air :

a.Syarat fisika : kekeruhan, temperatur, warna dan bau. b. Syarat kimia : pH, BOD, COD, kesadahan dan senyawa yang tidak mengandung kimia beracun. c. Syarat biologi : tidak mengandung bakteri pathogen misal bakteri golongan coli dan salmonella.

Beberapa upaya sehubungan dengan perkembangan teknologi dalam penyediaan dan pemanfaatan air diantarannya adalah teknologi tepat guna. Teknologi ini khususnya diperlukan untuk masyarakat pedesaan karena masyarakat pedesaan memerlukan teknologi tepat guna yang sederhana, efektif, efisien dan murah. Untuk mendapatkan air bersih dengan cara yang mudah dan relative murah, misalnya dengan cara penyaringan sederhana (filtrasi) dengan menggunakan media penyaringan antara lain: spon, pasir, koral, ijuk dan arang aktif.

Teknik pengolahan air bersih antaran lain dengan cara:

a. Filtrasi (penyaringan) merupakan proses pemisahan antara padatan dan koloid dengan cairan. Proses penyaringan bisa juga merupakan proses awal (primary treatment) (Kusnaedi, 2010). Media filter biasanya pasir atau kombinasi dari pasir, anthracite, garnet, ilmenite, polystyrene dan beads. Pasir yang paling baik dipakai untuk saringan bila pasir tersebut mengandung kwarsa $\left(\mathrm{SiO}_{2}\right)$ lebih besar atau sama dengan $90,8 \%$. Zat padat tersuspensi meliputi tanah, logam-logam teroksidasi dan mikroorganisme.

b. Flokulasi merupakan proses pembentukan flok-flok melalui pengadukan lambat setelah proses koagulasi. Ada beberapa flokulasi yaitu flokulasi secara mekanis, secara hidrolis dan penumatis. Di negara maju pengaduk mekanis lebih sesuai dari pada hidrolis karena lebih muda disesuaikan dengan variasi debit, suhu dan kualitas air baku (Purwoto, 2007).

c. Sedimentasi adalah proses pengendapan partikel-partikel padat yang tersuspensi dalam cairan atau zat cair karena pengaruh grafitasi (gaya berat secara alami). Proses pengendapan dengan cara grafitasi untuk mengendapkan partikel-partikel tersuspensi yang lebih berat dari pada air, proses ini yang paling banyak digunakan dalam pengolahan air. Sedimentasi dapat berlangsung sempurna pada air telaga/danau yang airnya diam atau suatu wadah air yang dibuat sedemikian rupa sehingga air di

**) Mahasiswa Teknik Lingkungan

*) Dosen Teknik Lingkungan Universitas PGRI Adi Buana Surabaya 
dalamnya dalam keadaan diam. Pada dasarnya proses tersebut tergantung pada pengaruh grafitasi dari partikel suspensi dalam air, sedimentasi dapat berlangsung pada setiap kadar air. Biaya pengolahan air dengan proses sedimentasi relative rendah karena tidak membutukan peralatan mekanik maupun penambahan bahan kimia, namun demikian paling sedikit dibutuhkan waktu 24 jam.

d. Aerasi, adalah proses pengolahan air secara mengontakannya dengan udara untuk bereaksi, dengan demikian terjadilah proses oksidasi. Dengan tujuan penambahan jumlah oksigen, penurunan jumlah karbon dioksida $\left(\mathrm{CO}_{2}\right)$, menghilangkan hydrogen sulfit $\left(\mathrm{H}_{2} \mathrm{~S}\right)$, methan $\left(\mathrm{CH}_{4}\right)$ dan berbagai senyawa-senyawa organik yang bersifat volatile (menguap) yang berkaitan rasa dan bau. Aerasi secara luas digunakan untuk pengolahan air yang mempunyai kandungan jumlah besi dan mangan terlalu tinggi. Zat-zat tersebut memberikan rasa pahit pada air, menghitamkan pemasakan beras dan memberikan noda hitam kecoklatcoklatan pada pakaian yang dicuci.

e. Netralisasi adalah suatu upaya agar air menjadi normal, setelah $\mathrm{pH}$ mendekati normal barulah proses pengolahan dapat dilakukan secara efektif. Pengaturan $\mathrm{pH}$ dalam instalasi air minum bertujuan untuk mengendalikan korosif perpipaan. Korosif membentuk racun pada $\mathrm{pH}$ kurang dari 6,3 atau lebih dari $9,5 \mathrm{pH}$ air secara alami dapat berkisar antara 4-9, dimana $\mathrm{pH}: 0$ disebut sangat asam, $\mathrm{pH}: 14$ disebut sangat basa, sedangkan $\mathrm{pH}: 7$ menunjukan netral pada suhu $25 \mathrm{C}$.

f. Densinfeksi berfungsi untuk membunuh bakteri pathogen (bakteri penyebab penyakit) yang penyebarannya melalui air, seperti penyakit typhus, cholera, disentri dan lain-lain.

Media Filtrasi Yang Digunakan antaran lain : Spon sebagai penyaringan awal, Pasir ayakan ukuran 0,45-0,55 mm bertujuan untuk mengurangi kandungan lumpur dan bahan-bahan padat yang terdapat dalam air, ljuk dan Koral yang berukuran 1-2 $\mathrm{cm}$ berfungsi untuk menagkap endapan, Arang aktif berukuran 1-2 $\mathrm{mm}$ berfungsi untuk mengurangi warna dan bau pada air kotor.

\section{RUMUSAN MASALAH}

Apakah ada pengaruh ketebalan media filtrasi arang aktif terhadap kekeruhan, warna dan TDS pada air telaga. Peranan Air Dalam Kehidupan Air merupakan materi yang essensial didalam kehidupan ,tidak ada makhluk hidup yang tidak membutuhkan air baik tumbuhan maupun hewan sebagian besar tersusun dari oleh air yaitu $75 \%$ isi sel tumbuh-tumbuhan dan76\% isi sel hewan tersusun oleh air (Suriawiryo,1986)

\section{TUJUAN PENELITIAN}

1. Untuk mengetahui tingkat kekeruhan, warna dan TDS pada air telaga di desa Balong panggang sebelum difiltrasi.

2. Untuk mengetahui tingkat kekeruhan air setelah di filtrasi dengan filtrasi 1 dan filtrasi 2.

3. Untuk mengetahui pengaruh ketebalan media arang aktif terhadap penurunan kekeruhan, warna dan total dissolved solid (TDS).

\section{METODOLOGI PENELITIAN.}

\section{A. Lokasi dan Waktu}

Pengambilan sampel air telaga dilakukan di desa Balongpanggang. Pada tanggal 22 Oktober 2013.

\section{Alat dan Bahan}

a) Media pasir lumajang

b) Drum/gentong, ukuran 100 liter

c) Spon

d) Koral, ukuran 5-10 mm

e) ljuk

f) Arang batok/arang aktif yang berbentuk butiran, diameter $5-15 \mathrm{~mm}$

\section{Sampel}

Air telaga desa Balong panggang Kecamatan Balong panggang, Kabupaten Gresik

\section{B. Variabel}

a. Variabel bebas pada penelitian ini adalah Penggunaan Media Arang Aktif pada Filtrasi.

b. Variabel terikat dalam penelitian ini adalah :

1. kekeruhan

2. warna

3.total dissolved solids (TDS).

c. Variabel yang Yang Dikendalikan

1. Jenis arang aktif yang digunakn berbentuk butiran dengan diameter 1 $2 \mathrm{~mm} 2$. Air baku yang diuji berasal dari air telaga di desa Balong Panggang. 3. Model pengolahan air adalah media filtrasi yang terdiri dari 2 
filter yang ukuran ketebalan media arang aktifnya berbeda :

a) Filter 1 yang terdiri dari spon $5 \mathrm{~cm}$, ijuk $10 \mathrm{~cm}$, koral $20 \mathrm{~cm}$, pasir 20 $\mathrm{cm}$, ijuk $10 \mathrm{~cm}$, arang aktif $10 \mathrm{~cm}$.

b) Filter 2 yang terdiri dari spon $5 \mathrm{~cm}$, ijuk $10 \mathrm{~cm}$, Koral $20 \mathrm{~cm}$, pasir 20 $\mathrm{cm}$, ijuk $10 \mathrm{~cm}$, arang aktif $20 \mathrm{~cm}$.

1. Debit aliran 2 liter/menit dengan pengambilan sampel percobaan ke 1 sampai ke 5 .

2. Lapisan dan media diatas arang aktif antara lain pasir, koral, ijuk dan spon.

\section{Langkah-langkah Penelitian}

a. Memastikan semua media dalam filtrasi telah terpasang dengan baik dan benar.

b. Air baku dari air telaga dengan menggunaka pompa air dimasukkan ke dalam tandon air baku, bagian atas tandon dipasang spon untuk penyaringan awal dan diberi lubang untuk stop kran. Kemudian stop kran ditutup terlebih dahulu selama kurang lebih 30 menit supaya air telaga tersebut mempunyai kesempatan untuk mengendap.

c. Air dari tandon air baku dialirkan ke tandon filtrasi atau filter penyaringan yang terdiri dari ijuk, arang aktif, pasir, krikil dengan cara membuka stop kran,

d. Pengukuran debit pada proses filtrasi dilakukan dengan cara membuka stop kran untuk mengalirkan air sampel dari tandon air baku yang mengalir dari atas ke bawah (grafitasi filtrasi) menuju tandon filtrasi sampai ke outlet dengan cara mengukur air dari outlet sebanyak 1 liter kemudian dihitung waktu yang diperlukan untuk menampung air tersebut. Pengukuran debit dilakukan sampai diperoleh nilai konstan (membiarkan sementara waktu air mengalir sampai alirannya stabil).

e. Setelah melewati filter penyaringan, air dialirkan ke bak penampungan air bersih melalui stop kran setelah 30 menit.

f. Selanjutnya dilakukan pengambilan sampel air sebanyak 4 kali percobaan untuk mengukur parameter kekeruan, warna dan TDS.

\section{HASIL PENELITIAN}

Dari hasil data kadar kekeruhan,warna,dan TDS di analisis dengan menggunakan efisiensi kadar secara treatment, kemudian di analisis dengan tabel dan

grafik.

Tabel 1. Hasil Pengamatan Uji Laboratorium Air Sampel Sesudah di Filtrasi 1 dan Filtrasi 2

\begin{tabular}{cccccccc}
\hline No & $\begin{array}{c}\text { Percobaan } \\
\text { (menit) }\end{array}$ & $\begin{array}{c}\text { Filtrasi 1 } \\
\text { kekeruhan }\end{array}$ & warna & TDS & $\begin{array}{c}\text { Filtrasi 2 } \\
\text { kekeruhan }\end{array}$ & warna & TDS \\
\hline 1 & 0 & 39,0 & 22 & 796 & 39,0 & 22 & 796 \\
2 & 30 & 2,02 & 18 & 227 & 7,64 & 2 & 176 \\
3 & 60 & 1,73 & 15 & 268 & 4,68 & 1 & 124 \\
4 & 90 & 2,10 & 15 & 270 & 3,47 & 2 & 143 \\
5 & 120 & 1,40 & 17 & 268 & 3,97 & 3 & 139 \\
\hline
\end{tabular}

Hasil penelitian awal air telaga di desa Balongpanggang kurang memenuhi syarat dan setelah di filtrasi 1 dan 2 dengan waktu 30 menit sebanyak 4 kali hasilnya memenuhi syarat air bersih.

Tabel 2. Hasil Analisis Prosentase Penurunan Uji Laboratorium Air Sampel Sesudah di Filtrasi 1 dan Filtrasi 2

\begin{tabular}{cccccccc}
\hline No & $\begin{array}{c}\text { Percobaan } \\
\text { (menit) }\end{array}$ & $\begin{array}{c}\% \\
\text { kekeruhan } \\
\text { (NTU) }\end{array}$ & $\begin{array}{c}\text { Filtrasi 1 } \\
\text { \% Warna } \\
\text { (TCU) }\end{array}$ & $\begin{array}{c}\text { \% Residu } \\
\text { terlarut } \\
\text { (TDS) }\end{array}$ & $\begin{array}{c}\text { F } \\
\text { Kekeruhan } \\
\text { (NTU) }\end{array}$ & $\begin{array}{c}\text { \% Warna } \\
\text { (TCU) }\end{array}$ & $\begin{array}{c}\text { \% Residu } \\
\text { terlarut } \\
\text { (TDS) }\end{array}$ \\
\hline 1 & 0 & 100 & 100 & 100 & 100 & 100 & 100 \\
2 & 30 & 94,82 & 18,18 & 71.48 & 80,41 & 90,91 & 77,88 \\
3 & 60 & 95,56 & 31,81 & 66,33 & 88 & 95,45 & 84,42 \\
4 & 90 & 94,61 & 31,81 & 66,08 & 91,10 & 90,91 & 81,78 \\
5 & 120 & 96,41 & 22,72 & 66,33 & 89,82 & 86,16 & 82,54 \\
\hline
\end{tabular}




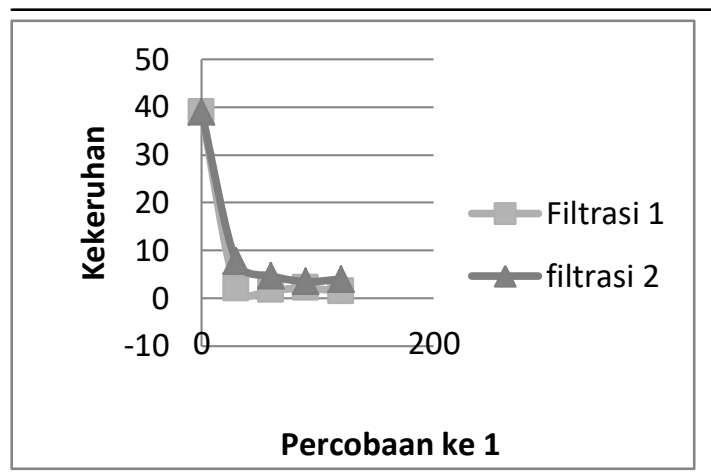

Grafik 1 : Prosentase Penurunan Kadar

Kekeruhan

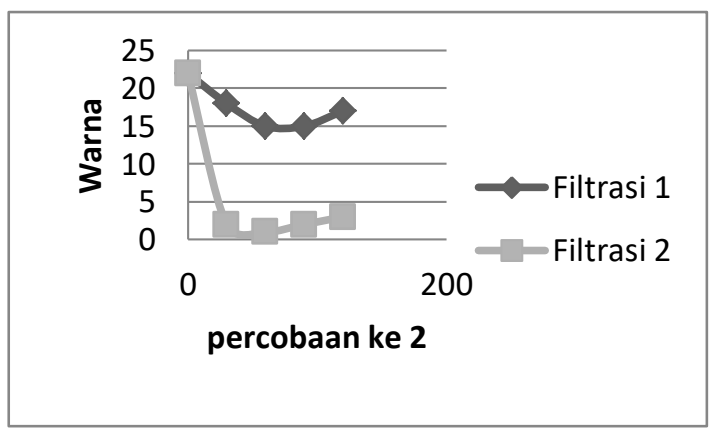

Grafik 2 : Prosentase Penurunan Kadar

Warna

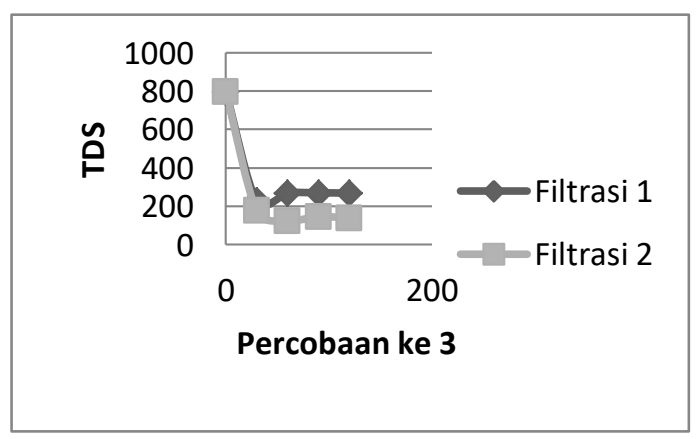

Grafik 3: Prosentase Penurunan Kadar

TDS

\section{PEMBAHASAN}

Dari data-data pemeriksaan uji laboratorium yang dilakukan pada air baku sebelum perlakuan/percobaan ke 1 untuk kadar kekeruhan $=39,0 \mathrm{NTU}$, Warna $=22$ TCU dan TDS = $796 \mathrm{mg} / \mathrm{l}$, Kemudian setelah dilakukan penyaringan (Filtrasi) pada percobaan ke 2 , air sudah mulai jernih dengan hasil pemeriksaan uji Laboratorium kadar kekeruhan $=2,02$ NTU turun 94,82\%, Warna $=18 \mathrm{TCU}$ dan TDS $=277 \mathrm{mg} / \mathrm{l} \mathrm{ini}$ pada filtrasi I. Untuk filtrasi 2 hasil percobaan uji Laboratorium kadar kekeruhan $=2,10$
NTU, Warna $=15$ TCU dan TDS $=270$ $\mathrm{mg} / \mathrm{l}$ Percobaan pengambilan air sampel diulang sampai 4 kali pada percobaan ke 5 , untuk filtrasi I kadar kekeruhan turun 96,82\%, Warna $22,72 \%$ dan TDS 66,33\% dibandingkan dengan filtrasi 2 kadar kekeruhan turun $89,82 \%$, Warna $31,81 \%$ dan TDS turun $68,22 \%$ sebab pada filtrasi 2 ketebalan arang aktifnya $(20 \mathrm{~cm})$ lebih tebal dibanding dengan filtrasi $1(10 \mathrm{~cm})$.

Dari hasil pemeriksaan uji laboratorium, setelah dilakukan percobaan pengambilan air sampel dengan filtrasi 1 dan 2 maka hasilnya semakin lama semakin jernih, sehingga filtrasi yang dihasilkan lebih baik (air lebih jernih) dengan waktu penyaringan yang relative lebih sedikit. Media filtrasi yang terdiri dari spon, ijuk, koral, arang aktif dapat menurunkan kadar kekeruhan, warna dan total dissolved solid (TDS). Filter 2 ( dengan arang aktif lebih banyak ) menghasilkan produk air dengan kadar kekeruhan, warna dan TDS yang lebih baik, karena dengan semakin banyak media arang aktif semakin banyak kadar kekeruhan, warna dan TDS yang diadsorbsi oleh arang aktif.

\section{KESIMPULAN DAN SARAN Kesimpulan}

Dari hasil dan analisa data dalam penelitian yang telah dilaksanakan maka dapat diambil kesimpulan sebagai berikut :

Air baku sebelum difiltrasi tingkat kekeruhannya 39,0 NTU, warna 22 TCU dan total dissolved solid (TDS) $796 \mathrm{mg} / \mathrm{l}$. 2. Hasil percobaan ke 2 pada filtrasi 1 untuk kadar kekeruhan 2,02 NTU, warna $18 \mathrm{TCU}$, dan TDS $227 \mathrm{mg} / \mathrm{l}$ dan filtrasi 2 untuk kadar kekeruhan 7,64 NTU, warna 2 TCU, dan TDS $176 \mathrm{mg} / \mathrm{l}$. 3. Filter 2 lebih efektif dengan ketebalan arang aktif setinggi $20 \mathrm{~cm}$, dapat menghasilkan produk air dengan kadar kekeruhan, warna dan TDS yang lebih baik, karena dengan semakin banyak media arang aktif semakin banyak kadar kekeruhan, warna dan TDS yang di adsorbsi oleh arang aktif.

\section{Saran}

Berdasarkan hasil eksperimen pada penelitian yang dilakukan maka:

Untuk mendapatkan air bersih yang sesuai dengan persyaratan standart mutu air bersih, masyarakat dapat mengolah air telaga dengan sistem filtrasi dengan kombinasi media ijuk, koral, pasir dan arang aktif sehingga masyarakat tidak lagi kekurangan air bersih untuk keperluan sehari-hari. 2 . 
Sangat cocok Filtrasi dengan media yang terdiri dari spon, ijuk, koral, pasir dan arang aktif, digunakan di daearah pedesaan karena selain membuatnya sangat mudah juga memerlukan biaya yang relative sedikit, tetapi mempunyai kelemahan yaitu pada debit yang dihasilkan sedikit karena hanya digunakan untuk skala rumah tangga. 3. Di dalam melakukan suatu penelitian dengan model pengolahan air bersih yang perlu diperhatikan adalah bahan-bahan atau media pengolah air bersih terutama yang ada disekitar lokasi dan hasil percobaan yang dilakukan,

\section{DAFTAR PUSTAKA}

Asmadi, Khayan, Kasjono,2011 “ Teknologi Pengolahan Air Minum “ Goysen Publishing, Yogyakarta.

Aswar Asrul, 1996, "Pengatur IImu Kesehatan Lingkungan". Jakarta, Mutiara Sumber Widya.

Daud, Anwar, 2007, "Aspek Kesehatan Penyediaan Air Bersih". Healthy \& Sanitation, Makasar.

Departemen Kesehatan RI, Peraturan Menteri Kesehatan RI Nomor : 416/MENKES/PER/IX/1990, tentang Syarat-syarat dan Pengawasan Kualitas Air Bersih.

Departemen Kesehatan RI, Peraturan Menteri Kesehatan RI Nomor : 429/MENKES/PER/IV/2010, tentang Standar Kualitas Air Minum.

Http/id:Wikipedia.org/wiki/air di akses pada tanggal 17 September 2013.

Http/id:Wikipedia.org/wiki/karbon aktif di akses pada tanggal 17 September 2013.

Kusnaedi, 2010, "Mengelolah Air Gambut dan Air Kotor untuk Air Minum". Jakarta, Penebar Swadaya.

Nasir, Moh, 2003, “Metode Penelitian”, Penerbit Ghalia Indonesia. Jakarta.

Pambi R.P. veronica, 2009 "Penurunana Tingkat Kekeruhan Pada Air Tanah Dangkal Dengan Filtrasi", Tugas Akhir Universitas PGRI Adi Buana Surabaya. 